\title{
Re-Establishing Microbial Role in Degradation of Organic Substrates: Population Dynamics of Starch-Hydrolysing, Cellulose-Degrading and Phosphate-Solubilising Bacteria from the Gut of Eudrilus Eugeniae (Kinberg)
}

\author{
Balraj Khobragade $^{1^{*}}$, Sayali More ${ }^{2}$ \\ ${ }^{1,2}$ PG Department of Zoology, Ahmednagar College, Ahmednagar (M.S.) India \\ balraj.indian@gmail.com
}

\begin{abstract}
This preliminary investigation attempted enumeration of total bacterial population as well as the starch-hydrolysing, cellulose-degrading and phosphate-solubilising bacteria from the gut of earthworm species Eudrilus eugeniae fed on organic substrates, namely leaf litter $(L L)$ and kitchen waste $(K W)$. The rapid increase in the population and morphometrics of earthworms indicated efficient utilisation of the substrates by them. The bacterial communities altered during the passage of organic material through the gut of E. eugeniae. Surprisingly, the total number of bacteria in the gut sample of earthworms fed on LL as well as KW was $4.4 x$ $10^{8} \mathrm{CFU} / \mathrm{gm}$. Analysis of population of different bacterial communities on various growth media indicated the presence of various enzyme producing bacteria in the gut of E. eugeniae. After 30 days of vermicomposting, the bacterial count in the gut sample of E. eugeniae able to hydrolyse the starch was found to be $3.3 \times 10^{8}$ and $3.4 \times$ $10^{8}$; degrade the cellulose was $3.1 \times 10^{8}$ and $3.2 \times 10^{8}$ and solubilise the phosphate was $3.2 \times 10^{8}$ and $3.3 \times 10^{8}$ CFU/gm, from LL and KW samples, respectively. Morphological variation among bacterial colonies appearing on solid media suggested that diverse bacteria are present in the gut of E. eugeniae. Further, biochemical characterisation and molecular identification is recommended so as to employ the potential bacterial activity in organic waste management to a greater extent.
\end{abstract}

Keywords: Organic wastes, vermicomposting, Eudrilus eugeniae, gut bacteria, enzymatic activity.

\section{INTRODUCTION}

Progress in science, technology, and industry has resulted in a large amount of waste ranging from raw sewage to nuclear waste is let out or dumped into the ecosystem, thereby posing a serious problem for survival of mankind itself on earth [1]. Modern agricultural practices make use of chemical fertilisers to boost crop production, which affects the total productivity of the crops and in the long run the soil becomes sterile and unfit for cultivation practices. In order to enhance the fertility status of the soil, the natural way of feeding the soil with different types of organic inputs (composts, vermicomposts, biofertilisers, farmyard manures, etc.) have been developed so as to ensure sustained productivity [2]. The use of biofertiliser is known to bring out several benefits to soil, solubilisation of essential minerals, get hold of nutrients, offering micronutrients in more utilisable form for plants, and taking part in biological nitrogen fixation [3]. Biofertilisers are low cost, effective and renewable sources of plant nutrients to supplement chemical fertilisers [4].

In sustainable agriculture, vermicompost plays a crucial role, wherein the organic wastes are converted into nutrient compounds with the help of earthworms as natural reactor [5]. Organic wastes from sewage, sludge, paper industry waste, urban residues, food and animal waste, and horticultural residues from cultivations have been successfully managed by vermicomposting producing vermicomposts that contain nutrients that are readily taken by plants [6]. Vermicomposts are finely divided peat-like materials with high porosity, aeration, drainage, water-holding capacity [7]. Recently, there is increasing interest in the potential of vermicompost as plant growth media and as soil amendment. The inherent microbial activity makes vermicompost an excellent soil amendment or conditioner [8]. Vermicompost improves soil structure, texture, aeration and water holding capacity. It adds beneficial microorganisms to the soil, which convert nutrients into a more available form for plants [9], and retains nutrients for long time and also protects crops from pests and diseases. It has high moisture holding capacity and hence also reduces the use of water for farm irrigation by $40-50 \%$ [10]. 
The biochemical decomposition of organic matter is primarily accomplished by the microbes; however, earthworms are crucial drivers of the process by fragmenting and conditioning the substrate, and by increasing the surface area of organic matter available for microbial attack after comminution [11]. Mucus secretion of earthworm brings about increase in microbial population [9]. Parthasarathi et al. [12] showed that the number of microorganisms present in the gut of earthworm depend on the substrate that the earthworm feed on. The composition of microflora in the earthworm gut varies depending on the species of earthworm studied, season and feeding regime of the earthworm [13]. Sruthy et al. [14] observed that there are variations in the population of microorganisms in the foregut, midgut and hindgut of earthworm, which may be because of their nutritional needs and the digesting ability of earthworms. Earlier work by Esakkiammal and Lakshmibai [15] involved analysis of the diversity of bacteria, fungi and actinomycetes in the gut of E. eugeniae fed on cowdung and leaf litter, wherein it was found that bacterial population was more in the midgut than foregut and hindgut region.

The microbial flora of earthworm gut and cast are potentially active and can digest a wide range of organic materials and polysaccharides including cellulose, sugars, chitin, lignin, starch and polylactic acids [16], [17], [18]. The complex organic molecules are digested through a mutualistic earthwormmicroflora digestion system. Amylase, cellulase, xylanase, endoglucanase, cellobiase, acid phosphatase, alkaline phosphatase and nitrate reductase produced by joint action of earthworms and gut microflora are supposed to play a central role in the process of digestion and humification of soil organic matter [19], [20]. Microorganisms are the most important sources for enzyme production [21], [22]. A wide array of digestive enzymes such as amylase, cellulase, protease, lipase, chitinase and urease were reported from earthworm's alimentary canal [23]. Enzymes, whether from animal, plant or microbial sources; are capable to act as biocatalyst for a wide variety of chemical reactions, where microbial enzymes are generally the most suitable for commercial applications [24].

Sivakumar et al. [25] tested the ability of the bacterial strain namely Bacillus cereus isolated from vermicompost site to produce the enzyme amylase. Nakamura and Kappamura [26] have reported the cellulolytic property of bacterial species like Pseudomonas, Cellulomonas, Cellulovibrio and Sporocytophaga sp. Shankar et al. [27] assessed the cellulolytic activity in the microbes isolated from the midgut of popular composting earthworm, E. eugeniae. Vijayakumar et al. [28] isolated and characterised cellulose-, phosphate- and lignin-degrading microflora from the gut of Perionyx excavatus and found that Bacillus sp, Pseudomonas sp, Cellulomonas sp, and Aspergillus niger degraded cellulose. Jacob et al. [29] isolated and screened the cellulose degrading microorganisms form the gut of composting earthworms for industrial applications. Isolation of phosphate solubilising bacteria from compost of agricultural wastes (rice straw, maize, groundnut, gliricidia leaf, and macrofauna dung) has been conducted by Hameeda et al. [30] and Nuraini et al. [31]. Chitrapriya et al. [32] isolated and identified phosphate solubilising bacteria namely Bacillus, Streptomyces and Pseudomonas and one nitrogen fixing bacteria namely Azotobacter from cow dung and saw dust vermicompost samples fed upon by E. eugeniae.

Epigeic earthworms live in the soil organic horizon and mainly feed on fresh organic matter contained in forest litter, litter mounds and herbivore dungs, as well as in man-made environments such as manure heap [33]. They are known to play a critical role in the decomposition of organic matter, thus significantly accelerating decomposition rates and nutrient turnover [34]. E. eugeniae which is commonly called 'African Night crawler' has high rates of growth and reproduction and is capable of decomposing large quantities of organic wastes rapidly [35]. The type of microorganisms involved depends on the environmental conditions [36]. Although microorganisms are responsible for the biochemical degradation of organic matter in the vermicomposting process, earthworms are important in conditioning the substrate and promoting microbial activity [6], [37]. Therefore, a need was felt to study the interaction between earthworm species and gut microbes, and the type of feed. The present investigation involved enumeration of starch hydrolysing, cellulose degrading, and phosphate solubilising bacteria from the gut of earthworm E. eugeniae.

\section{MATERIAL AND MeThodS}

The period of investigation extended from June 2015 to May 2016. The study was carried out in successive stages of viz., collection of organic wastes, namely leaf litter and kitchen waste from Ahmednagar College campus; vermicomposting operation employing the earthworm species Eudrilus eugeniae; its gut content sampling, enumeration of total bacterial population as well as that of starch 
Re-Establishing Microbial Role in Degradation of Organic Substrates: Population Dynamics of StarchHydrolysing, Cellulose-Degrading and Phosphate-Solubilising Bacteria from the Gut of Eudrilus Eugeniae (Kinberg)

hydrolysing, cellulose degrading and phosphate solubilising bacteria; using specific growth media at predetermined intervals.
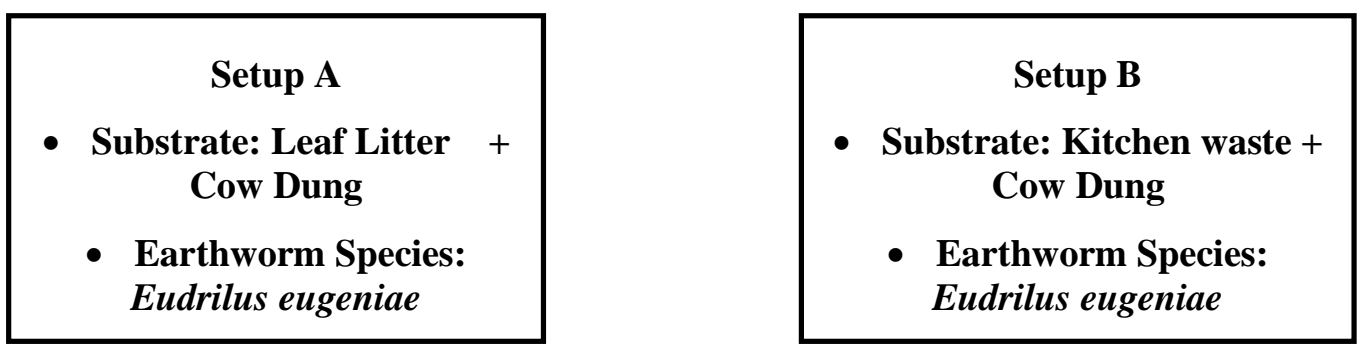

\subsection{Vermicomposting Operation}

Organic wastes in the form of leaf litter and kitchen waste were collected from Ahmednagar College campus. Kitchen waste was chopped into small pieces; whereas the dried leaf litter was crushed to small bits. The wastes were let to pre-decompose using cowdung slurry in the ratio of 3:1 for 20 days. As per Bajsa et al. [38], pre-composting comprises a short period of high temperature treatment followed by a period of lower temperature, facilitating mass reduction, waste stabilisation and pathogen reduction. After partial decomposition the substrates were taken into two experimental setups namely Setup 'A' for leaf litter and setup 'B' for kitchen waste. Earthworms of the species $E$. eugeniae were procured from Loni (Pravara), Dist. Ahmednagar. 50 no. of earthworms were released into each of the setup after measuring the length and weight of candidates for each of the setup. The set ups were covered with gunny bags to trap moisture and protect them from predators. Moisture content was maintained in the range of $45-65 \%$ by sprinkling water. The bedding was periodically turned in order to provide aeration and to release the initial heat produced during decomposition of organic matter. At pre-determined time intervals (i.e. 15, 30 and 45 days), few earthworms from each setup were used for bacteriological analysis of their gut content separately.

\subsection{Gut Content Sample Preparation}

2 to 4 earthworms from setup ' $A$ ' and ' $B$ ' were used separately at $15^{\text {th }}, 30^{\text {th }}$ and $45^{\text {th }}$ day after their introduction into the sets. They were sacrificed by dipping them in ice cold water, washed with sterile water and disinfected externally with $70 \%$ ethanol. Thereafter, they were dissected to expose the digestive tract and the gut contents were collected in two separate sterile plates and homogenised under aseptic conditions.

\subsection{Standard Plate Count of Bacterial Population from Gut Content Sample}

Serial dilution and agar plating of the gut content samples was conducted as per Dubey and Maheshwari [39]. $1 \mathrm{gm}$ of gut content was weighed and serially diluted from $10^{-1}$ to $10^{-7}$. From the serial dilution of Set A and Set B, aliquots of $0.1 \mathrm{ml}$ from $10^{-4}, 10^{-5}$ and $10^{-6}$ dilution were transferred aseptically using spread plate technique on Nutrient Agar plates; from $10^{-3}$ and $10^{-4}$ on Starch Agar plates, Carboxy Methyl Cellulose Agar (CMC) and Pikovskaya's medium agar plates for enumeration of bacteria. The Nutrient Agar and Starch Agar plates were incubated at $37^{\circ} \mathrm{C}$ for 48 hours, the CMC Agar plates were incubated at $37^{\circ} \mathrm{C}$ for 3 to 5 days and the Pikovskaya's Agar plates were incubated at $37^{\circ} \mathrm{C}$ for 5 to 7 days. The plates were observed daily for growth in the form of colonies for estimating the total bacterial population as well as starch hydrolysing, cellulose degrading and phosphate solubilising bacterial population. The starch agar plates were flooded with iodine solution; the CMC agar plates were flooded with $1 \%$ Congo Red solution \& allowed to react for $20 \mathrm{~min}$. at room temperature. Thereafter, the dye was discarded and the plates were counter-stained by flooding with $1 \mathrm{M} \mathrm{NaCl}$ for $15 \mathrm{~min}$. after which the solution was discarded; whereas the Pikovskaya's Agar plates after incubation period were observed for zone of clearance along the bacterial growth. The colonies were counted on each of the plates and the colony count was recorded and bacterial population was calculated in terms of colony forming units per gram (CFU/gm).

\section{RESUlts AND DiscuSSION}

The enzymes secreted by earthworms alone and/or in association with gut flora are responsible for decomposition of complex organic materials and humification of soil organic matter [40]. Earthworms 
have an in-house supply of enzymes such as protease, lipase, amylase, cellulase and chitinase; which degrade complex biomolecules into simple compounds utilisable by the symbiotic gut microflora. They speed up the composting process and transform wastes into nutrient rich castings with help of these enzymes [41].

The present investigation demonstrated variation in substrate and its effect on the total bacterial population, as well as that of different enzyme producing bacteria in the gut of the earthworm during the composting process. The difference in the initial and final number, mean increase in length and weight of earthworms from both the setups indicating that the earthworms fed on the organic substrates for their growth and reproduction and converted it into vermicast. As the vermicomposting of organic wastes proceeded, the number of earthworms approximately doubled in 45 days (see Table 1, and Figures 1 and 2).

Table1. Details of Earthworms introduced in the Vermibeds

\begin{tabular}{|c|c|c|c|c|}
\hline \multirow{2}{*}{$\begin{array}{c}\text { Earthworm Morphometrics \& } \\
\text { Number }\end{array}$} & \multicolumn{2}{|c|}{ Initial } & \multicolumn{2}{|c|}{ Linal } \\
\cline { 2 - 5 } Length (cm) & LL & KW & 14.3 & 15.2 \\
\hline $\mathbf{1}$ & 5.4 & 5.6 & 12.2 & 16.6 \\
\hline $\mathbf{3}$ & 3.2 & 4.7 & 13.3 & 14.2 \\
\hline $\mathbf{4}$ & 4.8 & 3.8 & 13.9 & 13.5 \\
\hline $\mathbf{5}$ & 6.0 & 6.4 & 16.3 & 12.8 \\
\hline $\mathbf{1}$ & 6.3 & 4.5 & 2.150 & 2.245 \\
\hline $\mathbf{2}$ & 0.230 & 0.250 & 2.980 & 2.230 \\
\hline $\mathbf{3}$ & 0.431 & 0.260 & 2.460 & 2.755 \\
\hline $\mathbf{5}$ & 0.229 & 0.350 & 2.450 & 2.440 \\
\hline Weight (gm) & 0.335 & 0.257 & 2.870 & 2.560 \\
\hline
\end{tabular}

The passage of organic wastes through the gut of E. eugeniae altered the bacterial populations therein. The CFU/gm of the gut sample on different growth media are given in Table 2. Sample plates of bacterial population in the vermicomposting samples on various growth media are shown in Plate 1, 2, 3 and 4 , respectively.

The CFU/gm of the gut sample were found to be highest on the Nutrient Agar plates at all the time intervals as is evident of the total bacterial count of the sample. The CFU/gm of the gut sample increased till $30^{\text {th }}$ day of vermicomposting, thereafter it decreased till $45^{\text {th }}$ day in both the gut samples fed on leaf litter and kitchen waste. This decrease may be due to the exhaustion of substrates in the experimental setup. Similar findings were reported by Lakshmi Prabha et al. [42] wherein significant higher amylase, lipase and cellulose activities were observed in vermicompost collected on $15^{\text {th }}$ day of decomposition by the Eisenia foetida and Eudrilus eugeniae than in other samples. They also found that with increase in inoculation time, the amylase, cellulase and lipase activities decreased steadily for both species and a low value of amylase, cellulose and lipase activity was found on $45^{\text {th }}$ day of vermicomposting.

Table2. Bacterial Population in the Gut of Eudrilus eugeniae (CFU $\left.\times 10^{8} / \mathrm{gm}\right)$

\begin{tabular}{|c|c|c|c|c|c|c|c|c|}
\hline \multirow{2}{*}{$\begin{array}{c}\text { Time Intervals } \\
\text { (Days) }\end{array}$} & \multicolumn{2}{|c|}{ Nutrient Agar } & \multicolumn{2}{c|}{ Starch Agar } & \multicolumn{2}{c|}{ CMC Agar } & \multicolumn{2}{c|}{ Pikovskaya's Agar } \\
\cline { 2 - 9 } & LL & KW & LL & KW & LL & KW & LL & KW \\
\hline $\mathbf{1 5}$ & 4.3 & 4.3 & 3.2 & 3.1 & 3.2 & 3.2 & 3.1 & 3.2 \\
\hline $\mathbf{3 0}$ & 4.4 & 4.4 & 3.3 & 3.4 & 3.1 & 3.2 & 3.2 & 3.3 \\
\hline $\mathbf{4 5}$ & 4.2 & 4.3 & 3.2 & 3.2 & 3.1 & 3.1 & 3.1 & 3.1 \\
\hline
\end{tabular}

In the present study, the total number of bacteria present in the gut of E. eugeniae after 30 days of composting was found to be $4.4 \times 10^{8} \mathrm{CFU} / \mathrm{gm}$ of the gut sample for both the substrates. The findings of the present study are in tune with that of Shankar et al. [27] who enumerated the number of cultivable aerobic bacteria present in the midgut of the earthworm E. eugeniae, which was $5.2 \times 10^{7}$ $\mathrm{CFU} / \mathrm{gm}$ of the gut sample.

Earthworms have shown higher activities of vital enzymes which are necessary to degrade complex biomolecules into simple compounds utilisable by symbiotic gut micro flora [43]. Microorganisms 
Re-Establishing Microbial Role in Degradation of Organic Substrates: Population Dynamics of StarchHydrolysing, Cellulose-Degrading and Phosphate-Solubilising Bacteria from the Gut of Eudrilus Eugeniae (Kinberg)

such as yeasts, fungi, bacteria, actinomycetes and algae are effectively producing amylase [44]. In the present study, the bacterial count in the gut sample of E. eugeniae able to hydrolyse the starch after 30 days of vermicomposting was found to be $3.3 \times 10^{8}$ and $3.4 \times 10^{8} \mathrm{CFU} / \mathrm{gm}$ of the gut sample for leaf litter and kitchen waste, respectively. The bacterial population points toward the presence of rich starch in the organic wastes used for vermicomposting. Similarly, the bacterial count in the gut sample of E. eugeniae able to degrade cellulose after 30 days of vermicomposting was found to $3.1 \times 10^{8}$ and $3.2 \times 10^{8} \mathrm{CFU} / \mathrm{gm}$ of the gut sample for leaf litter and kitchen waste, respectively. The bacterial count in the gut sample of E. eugeniae able to solubilise phosphate after 30 days of vermicomposting was found to $3.2 \times 10^{8}$ and $3.3 \times 10^{8} \mathrm{CFU} / \mathrm{gm}$ of the gut sample for leaf litter and kitchen waste, respectively.

Serfoji et al. [45] assessed the enzymatic activity during the course of decomposition of leaf litter and kitchen waste in the presence of epigeic earthworm species viz., Perionyx excavatus, Eudrilus eugeniae and Eisenia foetida at specific time intervals. The amylase, cellulase and lipase activity was high in vermicompost collected at $15^{\text {th }}$ day, which significantly decreased as the period increased. This work heavily depended on quantifying the enzyme activity in vermicomposts, whereas, the present investigation emphasised on enumeration of bacterial populations from the gut content of $E$. eugeniae which are able to hydrolyse starch, degrade cellulose and solubilise phosphates.

In the present investigation, CFU/gm of the gut sample from earthworm fed on leaf litter was found to be maximum on starch agar followed by cellulose agar and it was found to be minimum on Pikovskaya's agar. Whereas, the CFU/gm of the gut sample from earthworm fed on kitchen wastes it was found to be maximum on starch agar followed by Pikovskaya's agar and was found to be minimum on cellulose agar. Variation in the total bacterial population and bacteria able to hydrolyse starch, degrade cellulose and solubilise phosphate in the gut content of E. eugeniae fed on leaf litter and kitchen wastes, is as shown in Figures 3 and 4, respectively.

Considering the substrate used for vermicomposting, it was found that the CFU were maximum in the gut sample of earthworms fed on leaf litter on starch agar plates and CMC agar plates; whereas, the CFU were maximum in the gut sample of earthworms fed on kitchen wastes on Pikovskaya's agar. This suggests that the starch hydrolysing bacterial population was more in gut content of leaf litter fed earthworms, whereas, phosphate solubilising bacterial population was more in gut content of kitchen waste fed earthworms.

Bacteria grow on solid media as colonies. Different morphological characteristics of colonies on various agar plates were observed during the present study. The colony characteristics are given in Table 3.

The enumeration of bacterial population on various growth media and the variation observed in their colony characteristics suggest the presence diverse bacterial communities in the gut of E. eugeniae helping in the composting of the organic substrates.

Table3. Morphological Characteristics of Bacterial Colonies developed from Gut Content of E. eugeniae

\begin{tabular}{|l|c|c|c|c|c|c|}
\hline $\begin{array}{c}\text { Isolate } \\
\text { Code }\end{array}$ & SA1 & SA2 & SA3 & SB1 & SB2 & SB3 \\
\hline Size & $4 \mathrm{~mm}$ & $3 \mathrm{~mm}$ & Pinpoint & $2 \mathrm{~mm}$ & $5 \mathrm{~mm}$ & $4 \mathrm{~mm}$ \\
\hline Form & Irregular & Circular & Circular & Circular & Irregular & Filamentous \\
\hline Colour & Pale Yellow & Off-white & White & Orange & Off-white & White \\
\hline Surface & Smooth & Smooth & Smooth & Smooth & Rough & Smooth \\
\hline Margin & Entire & Entire & Entire & Entire & Lobate & Filiform \\
\hline Texture & Butyrous & Dry & Dry & Butyrous & Brittle & Mucoid \\
\hline Elevation & Convex & Flat & Flat & Raised & Flat & Flat \\
\hline Opacity & Opaque & Opaque & Translucent & Opaque & Opaque & Opaque \\
\hline
\end{tabular}




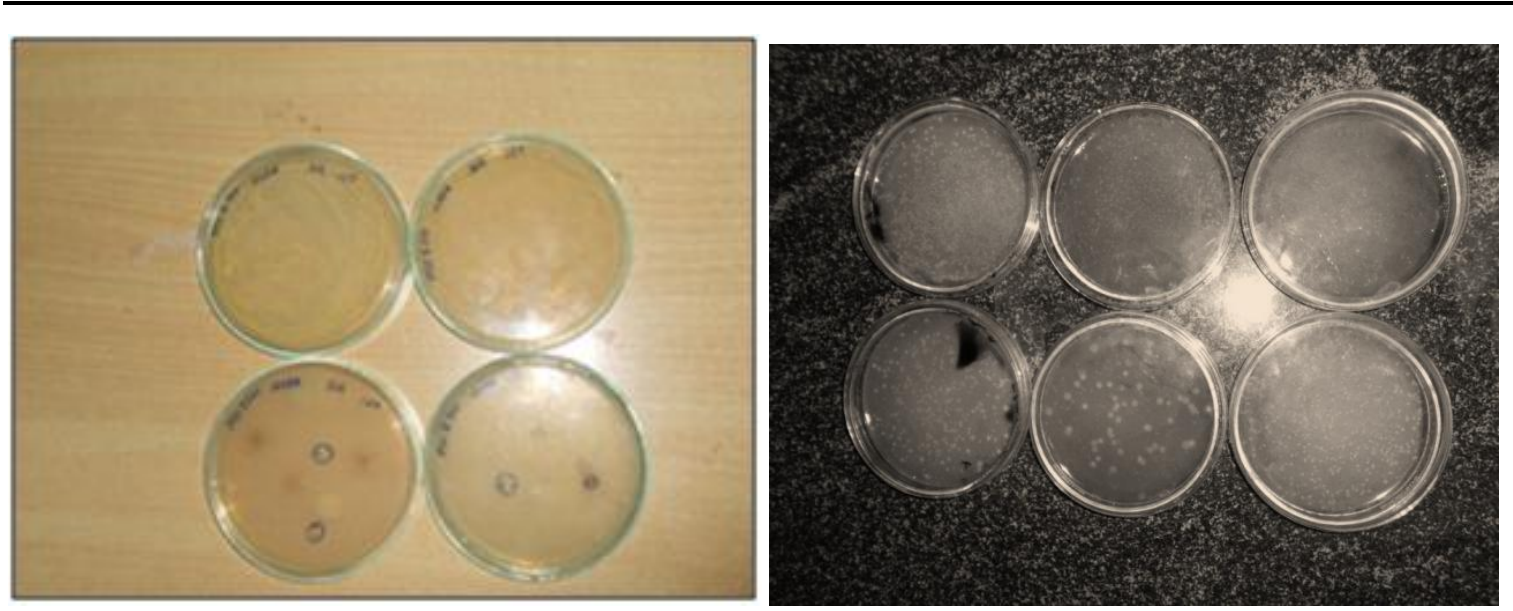

Bacterial Growth as seen on Plate 1. Nutrient Agar Plates and Plate 2. Starch Agar Plates
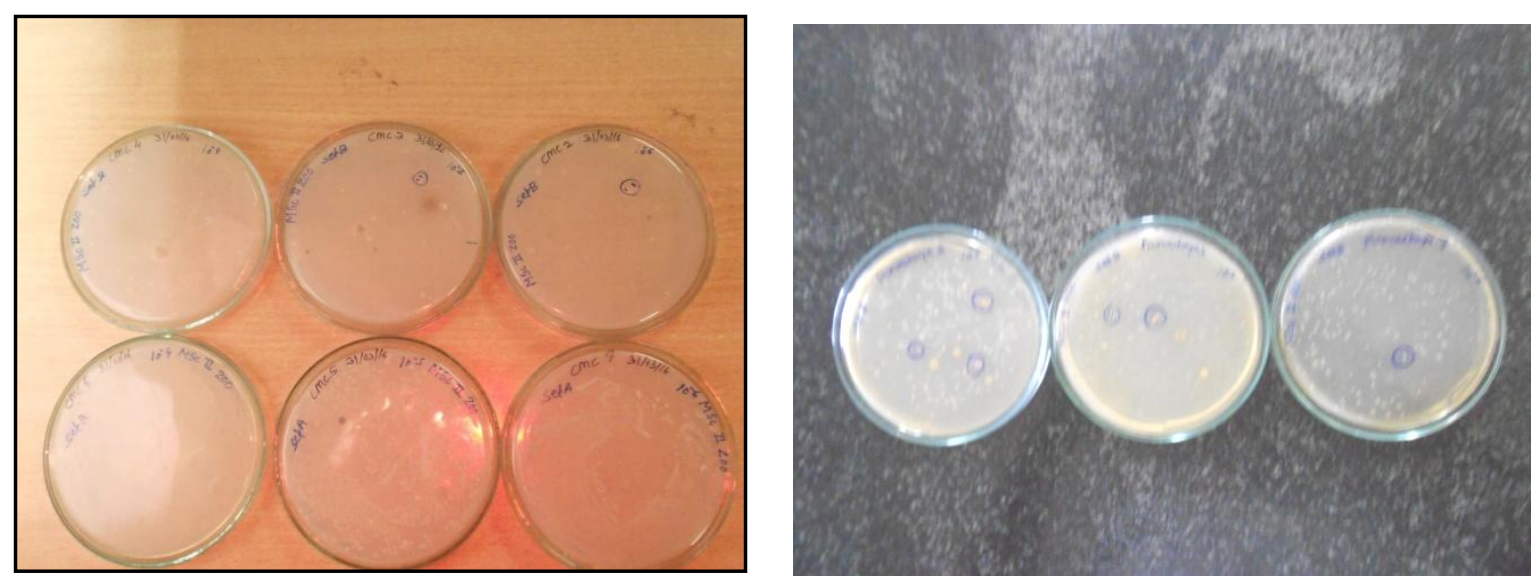

Bacterial Growth as seen on Plate 3. Carboxy Methyl Cellulose Agar Plates and Plate 4. Pikovskaya's Agar Plates

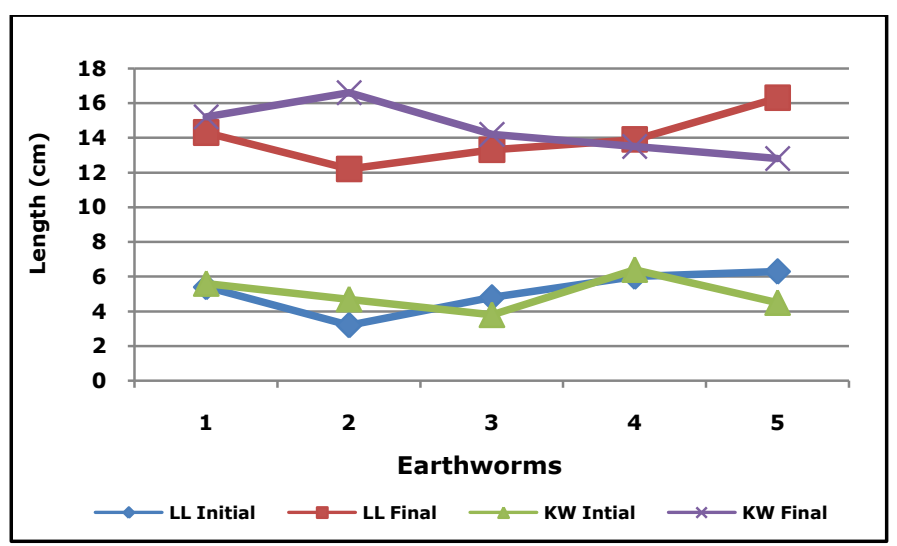

Fig1. Change in Growth Parameters of Earthworms during Vermicomposting

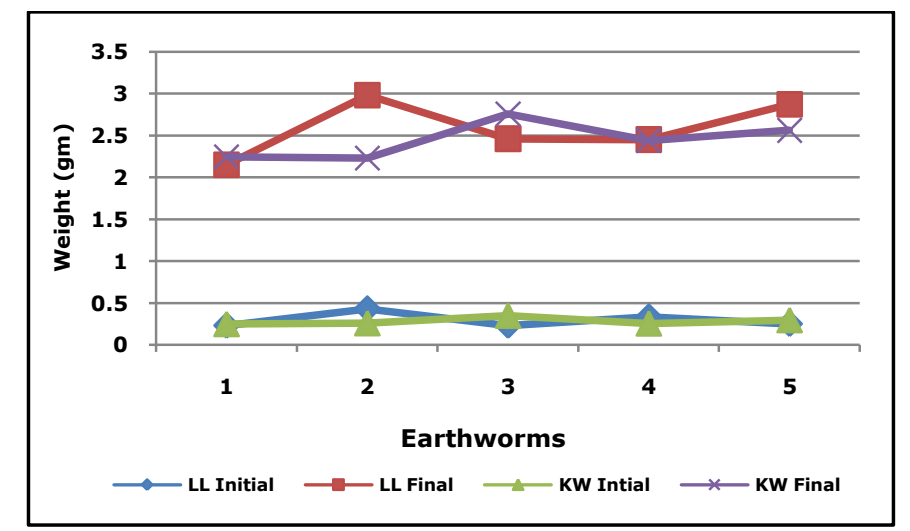

Fig2. Change in Growth Parameters of Earthworms during Vermicomposting 
Re-Establishing Microbial Role in Degradation of Organic Substrates: Population Dynamics of StarchHydrolysing, Cellulose-Degrading and Phosphate-Solubilising Bacteria from the Gut of Eudrilus Eugeniae (Kinberg)

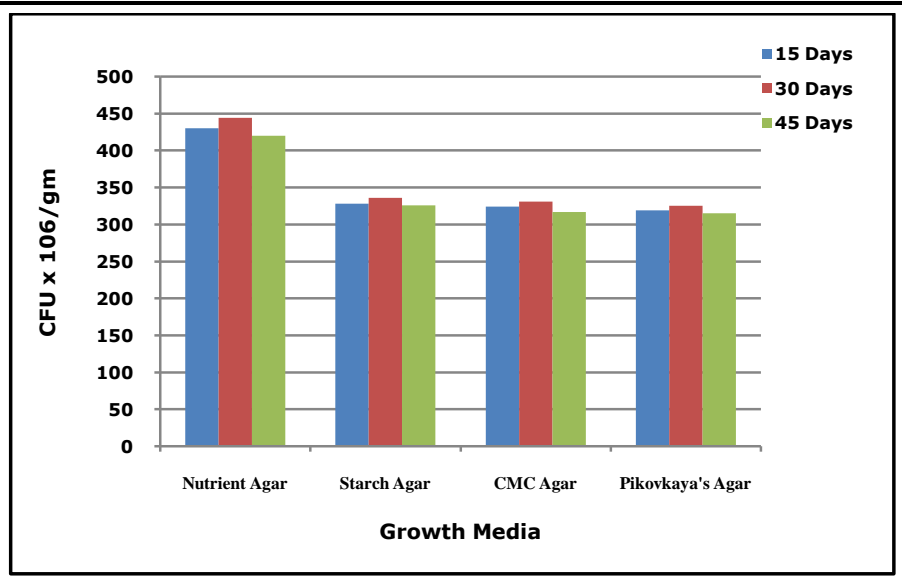

Fig3. Bacterial Population in Gut of Eudrilus eugeniae Fed on Leaf Litter

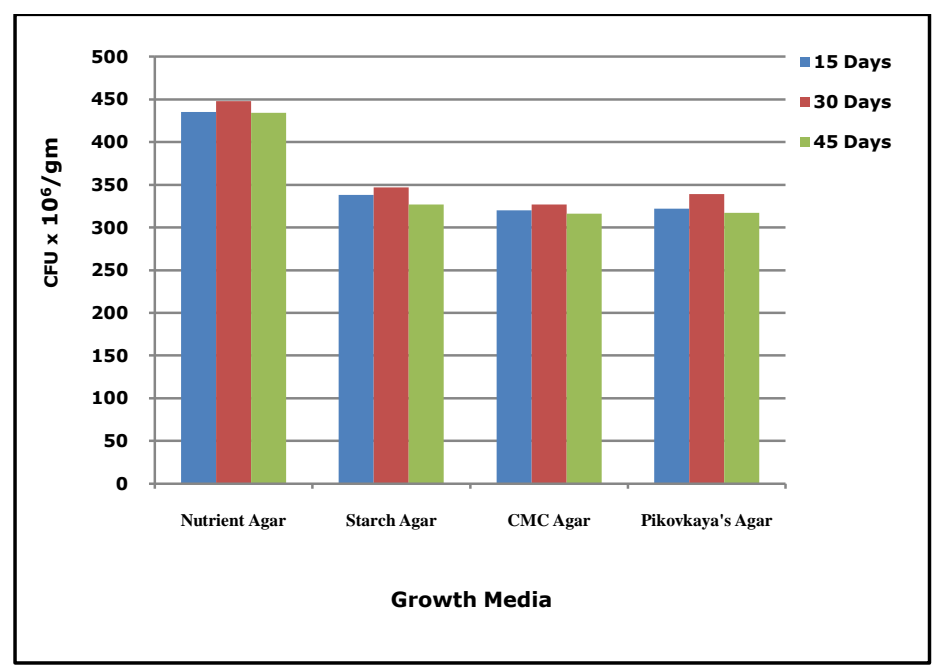

Fig4. Bacterial Population in Gut of Eudrilus eugeniae Fed on Kitchen Waste

\section{Conclusions}

Present study provides evidence for amylase, cellulase and phosphatase enzyme producing ability of the earthworm gut bacteria, as is evident from the enumeration of bacterial populations in the form $\mathrm{CFU} / \mathrm{gm}$ of the gut sample on various growth media. The different bacterial colony morphologies observed during the study suggest the presence of diverse bacterial communities inhabiting the gut of Eudrilus eugeniae. The outcome of the present study reaffirms the role of the earthworm E. eugeniae in efficient recycling of the leaf litter and kitchen waste into farm manure, thereby preventing environmental pollution in case they are left on the mercy of nature.

As observed in earlier works, low cost substrates such as leaf litter and kitchen waste could be converted into a potent natural fertiliser by the action of abundant starch hydrolysing, cellulose degrading and phosphate solubilising bacterial populations lodging earthworm gut. Organic wastes as mentioned above are generated in enormous quantities in human society and the same can be converted into nutritionally rich biofertilser using earthworms as bioreaction agents. The inherent capacity of various bacterial populations in earthworm gut to produce an array of different enzymes could be directed for ecofriendly treatment of organic wastes. The vermicompost thus obtained and applied could result in luxuriant plant growth, especially of agricultural crops, increasing their yield and making organic farming a profitable venture.

\section{ACKNOWLEDGEMENTS}

The authors are grateful to The Principal, Ahmednagar College, Ahmednagar for his constant support and motivation in their research endeavours. They are also thankful to The Head, Department of Zoology and Biotechnology, Ahmednagar College, Ahmednagar; for providing laboratory and library facilities for the study. 


\section{REFERENCES}

[1] Karigar Chandrakant S. and Shwetha S. Rao (2011). Role of microbial enzymes in the bioremediation of pollutants: A review. SAGE-Hindawi Access to Research Enzyme Research Volume, Article ID 805187, 11 pages.

[2] Bhawalkar U.S. (1996). Vermiculture Ecotechnology, Earthworm Research Institute, Pune, India, $2^{\text {nd }}$ edition.

[3]Rajasekar Kuppuraj, Thilagavathy Daniel and Natchimuthu Karmegam (2012). Microbial enrichment of vermicompost. 1-13.

[4] Boraste A., Vamsi K.K., Jhadav A., Khairnar Y., Gupta N., Trivedi S., Patil P., Gupta G., Gupta M., Mujapara A.K. and B. Joshi (2009). Biofertilizers: A novel tool for agricultural. 1(2): 23-31.

[5] Arancon N.G., Edwards C.A., Babenko A., Cannon J., Galvis P and J.D. Metzger (2008). Influences of vermicomposts, produced by earthworms and microorganisms from cattle manure, food waste and paper waste, on the germination, growth and flowering of petunias in greenhouse. Applied soil ecology, 39: 91-99.

[6] Dominguez J. (2004). State of the art and new perspectives in vermicomposting research, In: Edwards, CA (Ed.), Earthworm Ecology. $2^{\text {nd }}$ ed. CRC Press, Boca Raton, pp: 401-425.

[7] Dominguez J., Edwards C. and S. Subler (1997). A comparison of vermicomosting and composting. Biocycle.

[8] Atiyeh R.M., C.A. Edwards, S. Subler and J. Metzger (2000). Earthworm processed organic wastes as components of horticultural potting media for growing manifold and vegetable seedlings. Compost Science and Utilization, 8(3):215-223.

[9] Scheu S. (1991). Mucus excretion and carbon turnover of endogenic earthworms. Biol. Fert. Soils, 12(1): 217-20.

[10] Sinha Rajiv K. and Sunil Herat (2012). Organic farming: Producing chemical-free, nutritive and protective food for the society while also protecting the farm soil by earthworms and vermicompost-reviving the dreams of Sir Charles Darwin. 2(5):217-239.

[11] Domi'nguez J., Aira M. and M. Go'mez-Brando'n (2010). Vermicomposting: Earthworms Enhance the Work of Microbes. In: Insam H, Franke-Whittle I, Goberna M, eds. Microbes at Work: from Wastes to Resources. Springer-Verlag. pp 93-114.

[12] Parthasarathi K., Ranganathan L.S., Anandi V. and J. Zeyer (2007). Diversity of microflora in the gut and casts of tropical composting earthworms reared on different substrates. J. Environ. Biol., 28: 87-97.

[13] Kristufek V., Ravasz K. and V. Pizl (1992). Changes in densities of bacteria and microfungi during gut transit in Lumbricus rubellus and Aporrectodea caliginosa Oligochaeta: Lumbricidae). Soil Biol. Biochem., 12:1499 1500.

[14] Sruthy et al. (2013) Screening of earthworm Eudrilus eugeniae gut as a transient microbial habitat, Advances in zoology and botany 1(3): 53-56.

[15] Esakkiammal B. and L. Lakshmibai (2013). Enumeration of bacterial population in the gut region of Eudrilus eugeniae. Int. J. Curr. Microbiol. App. Sci, 2(5): 267-270.

[16] Zhang B.G., G.T. Li, T.S. Shen, J.K. Wang and Z. Sun (2000) Changes in microbial biomass C, $\mathrm{N}$, and $\mathrm{P}$ and enzyme activities in soil incubated with the earthworms Metaphire guillelmi or Eisenia foetida. Soil Biol Biochem, 32: 2055-2062.

[17] Aira M., Monroy F. and J. Domı'nguez (2007). Eisenia foetida (Oligochaeta: Lumbricidae) modifies the structure and physiological capabilities of microbial communities improving carbon mineralization during vermicomposting of pig manure. Microbial Ecol, 54: 662-671.

[18] Vivas A., B. Moreno, S Garcia-Rodriguez and E. Benitez (2009). Assessing the impact of composting and vermicomposting on bacterial community size and structure, and functional diversity of an olive-mill waste. Bioresour Technol, 100: 1319-1326.

[19] Jolly et al. (1997). Scanning Electron Microscopy of the Gut Microflora of Two Earthworms: Lumbricus terrestris and Octolasion cyaneum, Microb. Ecol. (1993) 26: 235-245. 
Re-Establishing Microbial Role in Degradation of Organic Substrates: Population Dynamics of StarchHydrolysing, Cellulose-Degrading and Phosphate-Solubilising Bacteria from the Gut of Eudrilus Eugeniae (Kinberg)

[20] Indira and Lakshmi (2007). Comparative studies on the digestive enzymes in the gut of earthworms, Eudrilus eugeniae and Eisenia foetida. Indian Journal of Biotechnology, Vol 6, pp 567-569.

[21] Pandey A., Nigam P., Soccol C.R., Soccol V.T., Singh D. and R. Mohan (2000). Biotechnol. Appl. Biochem, 31: 135-152.

[22] Ashwini K., Gaurav Kumar, Karthik L. and K. V. Bhaskara Rao (2011). Scholars Research Library.

[23] Munnoli P.M., J.A.T. Da Silva and B. Saroj (2010). Dynamics of the soil-earthworm-plant relationship: a review. Dynamic soil, dynamic plant: 1-21.

[24] Neidleman S.L. (1997). Enzymes and microbes a source of chemical diversity. In: High throughput screening - The discovery of bioactive substance. Eds., J.P. Devlin and I.N.C. Marcel Decker, New York, pp: 77-98.

[25] Sivakumar T. Shankar, P. Vijayabaskar, J. Muthukumar and E. Nagendrakannan T. (2012). Amylase production using Bacillus cereus isolated from a vermicompost site. International Journal of Microbiological Research, 3 (2): 117-123.

[26] Nakamura K. and K. Kppamura (1982). Isolation and identification of crystalline cellulose hydrolyzing bacterium and its enzymatic properties. J. Ferment. Technol., 60(4): 343-348.

[27] Shankar T., Mariappan V. and L. Isaiarasu (2011). Screening cellulolytic bacteria from the midgut of the popular composting earthworm, Eudrilus eugeniae (Kinberg). World J. Zool, 6: 142148.

[28] Vijayakumar B., Shanmugasundaram, Menaga P., Saranya V., Sujatha R. and Vijey Anandhi (2009). A study on isolation and characterization of Earthworm gut flora of Perionyx excavates. Biomedical \& Pharmacology Journal Vol. 2(2): 403-406.

[29] Jacob Krupa Mary, Ashitha George, Manjusha, Mythili Sathiavelu and Sathiavelu (2014). An isolation and screening of cellulose degrading microorganisms from the gut of composting earthworms and its industrial applications. Research Journal of Pharmaceutical, Biological and Chemical Sciences May-June 2014 RJPBCS, 5(3): 501-507.

[30] Hameeda B., Harini G., Rupela O.P., Wani S.P. and G. Reddy (2008). Growth promotion of maize by phosphate solubilizing bacteria isolated from composts and macrofauna. Microbiological Research, 163: 234-242.

[31] Nuraini Y., Abadi A.L., Soemarno and T. Ardyati (2011). Potensial of legume and maize to stimulate population of nitrogen-fixing bacteria, phosphate-solubilizing bacteria and indole acetic acid production. Journal of Agriculture and Food Technology, 1(12): 218-226.

[32] Chitrapriya K., Asokan S. and R. Nagarajan (2013). Estimating the level of phosphate solubilising bacteria and Azotobacter in the vermicompost of Eudrilus eugeniae and Perionyx excavatus with various combinations of cow-dung and saw-dust. International Journal of Scientific and Research Publications, 3(10): 2250-3153.

[33] Aira M., Sampedro L., Monroy F. and J. Domı'nguez (2008). Detritivorous earthworms directly modify the structure, thus altering the functioning of a microdecomposer food web. Soil Biol Biochem, 40: 2511-2516.

[34] Lavelle P. and A.V. Spain (2001). Soil Ecology. London: Kluwer Academic Publishers.

[35] Pattnaik and M. Vikram Reddy (2010). Heavy metals remediation from urban wastes using three species of earthworm (Eudrilus eugeniae, Eisenia foetida and Perionyx excavatus). J. of Environ. Che. and Ecotoxicology, 3(14): 345-356.

[36] Lynd L.R., Weimer P.J., Van Zyl. W.H. and I.S. Pretorius (2002). Microbial cellulose utilization: Fundamentals and biotechnology. Microbiol. Mol.Biol. Rev., 66: 506-577.

[37] Katheem Kiyasudeen S., Jessy R.S. and M.H. Ibrahim (2014). Earthworm's gut as reactor in vermicomposting process: A mini review. International Journal of Scientific and Research Publications, 4(7): 1-5.

[38] Bajsa O. et al. (2003). Vermiculture as a tool for domestic wastewater management. Water Science and Technology, 48(11-12): 125-132. 
[39] Dubey R.C. and D.K. Maheshwari (2002). Practical Microbiology. S. Chand and Company Ltd., Ramnagar, New-Delhi, 1-413.

[40] Dharmalingam K., (2005). Proceedings of the National level Conference on vermitechnolgy transfer to NSS programme officers (R. Jeyaraj and Indira A. Jeyaraaj (eds.) Rohini Press, Coimbatore, Tamil Nadu, India.

[41] Kumar J.A. (2004). Effect of Vermicomposted sludge on growth of Amaranthus dubilum. J. Ecotaxicol. Environ. Monit., 14:157-160.

[42] Lakshmi Prabha M., Jayaraj Indira A. and R. Jeyaraaj (2004). Activity of selected enzymes during the course of decomposition of fruit waste in presence of earth worms, J. Soil Biol., 24 (12): $167-172$.

[43] Lakshmi Prabha M. and R.S. Achsah (2013). Potential of vermicompost produced from banana waste (Musa paradisiaca) on the growth parameters of Solanum lycopersicum. International Journal of Chem. Tech. Research, 5(5): 2141-2153.

[44] Pandey A. (2003). Solid state fermentation. Biochem. Eng. J., 13: 81-84.

[45] Serfoji P., Siva T. and R. Devi (2015). Studies on enzyme activity of earthworm cast from Kitchen waste with cow dung. Species, 14(42): 1-10. 